\title{
THE PECULIARITIES OF NATIONAL IDENTITY OF AUSTRALIAN UKRAINIANS IN THE WORKS OF L. BOHUSLAVETS
}

\author{
Galyna Gandzilevska, \\ Tetiana Shyriaieva \\ National University of Ostroh Academy, Ukraine \\ E-mail: handzilevskahalyna@gmail.com, \\ tetiana.shyriaeva@oa.edu.ua
}

\begin{abstract}
After a period of continuous troubles that Ukraine has witnessed over a period of its history, the issue of national identity today appears to be more acute than ever before. It is explained by various reasons that are not under consideration in this research. However, the notion of national identity, its factors and modern perspectives are of a great scientific importance. Amid the principles of identity there is one that refers to the existential feeling of belonging and the desire to unite in factions with those who share similar interests. Besides, national identity is viewed as the factor that affects the preservation and development of the Ukrainian nation. The paper presents the research with aim to define the national identity and its integral parts that are essential for identity preservation. National identity is understood as a collective structure that illustrates how similar or different the elements of society are. Five factors of national identity that are considered in the paper are the collective identification that is realized in religious and cultural beliefs, common history and the feeling of belonging, active social life, which is illustrated by one's participation in cultural activities, geographical belonging and national character that is a set of cultural believes followed by the representatives of a particular national group. The literary work of Lesia Bohuslavets, a Ukrainian immigrant who lives in Australia, is under consideration in this paper. She was defined as a writer under analysis as she is viewed as an example of those conscientious Ukrainians who feel responsible for cultural and national preservation. The literary work "My Australian kuma" of Lesia Bohuslavets was analysed by means of content analysis which is a statistic means of language evaluation. The result of content analysis proved that national character and active social life categories were marked with the highest variables. It means that exactly these factors are the most influential in the context of national identity preservation.
\end{abstract} Key words: active social participation, content analysis, national character, national identity.

\section{Introduction}

Modern Ukrainian history undergoes considerable transformations. It can be explained by the fact that national believes and values are much dependent on social and political aspects of people's life. However, national identity can be perceived as an integral component of the social identity which is in close relation to one's self-understanding, self-evaluation and personal refer- 
ence to the extended national group. Besides, national group is formed of the representatives of a community who are motivated to reach socially important purpose and influence cultural, intellectual and economic aspects of national life. The issue of national identity appears to be of a great importance concerning Ukraine, which is on its way to construct the positive image of the ethnic category 'Ukrainian'. Moreover, one should not neglect the importance of psychological barriers that hamper the process of national identification among Ukrainians.

The factors that influence national identity and their perspectives are widely viewed by social and cultural anthropologists and psychologists (Berger, Luckmann, 1966; Mead, 2009; Berry, 1992). Theoretical analysis of various conceptual approaches shows that identity is a result of the process of identification which means resemblance with particular individual or ethnic group. Identity is viewed as the main mechanism of socialisation and ethnic belonging. So, identity in this context appears to be a dynamic structure that can be developed through the life span of an individual; it presupposes the successful dealing with the identity crises and can be either progressive or regressive (Voropaeva, 2009). High level of religiousness and morality of Ukrainians is explained by their long-lasting struggle for prevalence that results from the fact that Ukrainians were historically less numerous than the nations that inhabited the territory of their country (Gnatenko, 1997). Later, as one of the former USSR republic Ukraine became characterized with the high level of soviet identity which dominated over ethnic, social, European and human identities (Gnatenko, Pavlenko, 1999). Moreover, there is an idea that no nation is a really existing community as it finds its importance only in the minds of its representatives (Anderson, 2001). It goes without saying that all possible difficulties of understanding Ukrainian nation and its peculiarities have influenced national separation so that immigration became quite popular.

\section{Research Problem}

Actually, national identity is considered as one's unique feeling of belonging to a certain nation that presupposes the knowledge of language, religious and ethnic peculiarities, and cultural heritage. Moreover, it is a unique phenomenon that cannot be studied as far as it is demonstrated in numerous ways by representatives of various nations. However, in the light of historic transformations national identity can be preserved if the peculiarities of immigrants' feeling of national identity are clear enough. The feeling of national belonging and national identity can be observed in the works of Ukrainian immigrant writers. On the one hand, a language analysis of their works enables scientists to conduct their researches and to find out the valid results. On the other hand, the majority of literary works that are done outside Ukraine not only reflects the peculiarities of the life of Ukrainian immigrants, but contains the information which is directly connected with the issue of national identity preservation. Literature is a good source to study national identity as it presents the objective and acute information (Kominiarska, 2012). Matsko (2010) compares literature to scientific papers and emphasizes that the first has more flexible conceptual apparatus than latter that enables the examination of one's subconscious level and its relation to the objective world using suggestive means and metaphors. Moreover, it makes possible to model the possible forthcoming future. Kominiarska (2012) believes the literature written by Diaspora is of a great importance, as its writers 'wished to positively influence the formation of Ukrainian national self-consciousness that is characterized by rich history and future' (Kominiarska, 2012, p. 206). Thus, hypothetically the selection of the personalities of talented immigrants and psychological analysis of their literary works will provide the possibility to recollect past experience with the aim to develop and preserve national identity in the conditions of nowadays. In this paper the work of the member of Writer's Union in Ukraine Lesia Bohuslavets is considered. Such choice of this prominent writer can be explained by her membership in the artistic club "Triumph". Moreover, she is a daughter of the famous immigrant activist in Australia and the editor of the almanac "New horizon" Dmytro Nytchenko (Chub). Together with her family Lesia Bohuslavets (Tkach) immigrated to Australia in 1943, however, she regularly visits Ukraine. In this research many personal facts that were kindly provided by Lesia Bohuslavets in her private communication with the authors of the research are considered. 


\section{Research Focus}

Matsko (2010) has analyzed the novels of XX century written by Diaspora authors and claimed that the overwhelming majority of them, including the works of L. Bohuslavets, are left unknown to the majority. However, it is she whose legacy is said to strengthen national confidence as well as to develop its uniqueness and believes in the independence of Ukraine. National ideas are discussed with a view of personal sacrifice, freedom of choice and the importance of one's life in the situation of global historical disasters. Analysis of these works will provide the answers for the question, such as how the national identity was preserved in the light of Ukrainian integration into the universal cultural situations.

Angelutsa (2001) sees literary works of Oleksandra Tkach, which she published under the pseudonym Lesia Bohuslavets, as those that are oriented on the exposition of style of life and psychology of Ukrainians in Australia. Kominiarska (2012) underlines that the identity of the writer as an organic unity exists exclusively under the condition when "the national identity of the individuality of author and the national identity of the literary work correlate". She continues by saying that "the inner freedom of personality is an integral element of the national identity of the hero of any particular literary work" (Kominiarska, 2012, p. 208). Examining "Eneida" and looking for the representations of national identity there, Maltseva (2009) emphasizes the therapeutic power of humour and laughing. Thus, Bohuslavets's autobiographic work "My Australian kuma" appears of an exceptional importance. Its scientific interest is explained by the uniqueness of the lines of its heroes. Kominiarska (2012) understands exact words of the protagonists as "the way they see their own identity". Moreover, being a researcher of the works of Ulas Samchuk, she pays attention to the fact that writers frequently use folklore in their literature since numerous proverbs and sayings "help to create the image of heroes and to illustrate their real thoughts". In other words, the researcher believes that these are humour, satire and lyrical nature of the literary works that are the exact tools used by writers to give the sense of identity of the heroes. Moreover, it helps to depict the tradition of folk (Matsko, 2010). Irony, grotesque and satiric hyperbole make these works stand out from the rest of the literary works of a particular period. However, humour and satire do not influence the seriousness of the general sense of any of these pieces of writing.

Thus, the aim of this research is as follows: 1) to investigate the main biographical facts of Lesia Bohuslavets and her relation to the phenomenon of national identity of Ukrainian immigrants; 2) to speculate the factors that are essential for genuine understanding of national identity; 3 ) to analyse Bohuslavets's literary work 'My Australian kuma' by means of content analysis, which is "a technique for making inferences by objectively and systematically identifying specified characteristics of messages" (Holsti, 1969) and to define the factors of national identity that are expressed in her work.

\section{Methodology of Research}

\section{General Background of Research}

In line with an aim of a research, it was decided to consider the life of Oleksandra Tkach and to statistically examine her work 'My Australian kuma' considering the used vocabulary by means of which the writer explained her thoughts. Both aspects are seen to be influential for the general understanding of national identity preservation of Australian Ukrainians. The contemplation of writer's life provides enough evidence to assume that immigrants mind the term 'national identity' no matter how long they are living abroad. Moreover, her personal ideas and facts of her life can be proved by means of statistics for what the language of her literary work was considered. This provides factual data. Moreover, the figures that are got as a result of an analysis can prove the preliminary assumptions that as far as immigrants live on the territory other than their native land, the feelings of cultural belonging and social activity should be mostly demonstrated in the literary works of immigrants.

In her private letters sent on October 31, 2013 Oleksandra Tkach states her personal reasons 
for becoming a writer. She says, 'I wanted to draw attention to the drawbacks of the modern life. I believed that describing myself as the one who is characterized by the negative features I made my work be understood by the readers in a better way'. Moreover, her father, as it becomes obvious from her letters, was fond of humorous novels, especially those of Stepan Rudanskiy. In one of the issues of Almanac (1974) in his article 'Ukrainian humour and its creators' Dmytro Nytchenko writes, "when we speak about Ukrainian humour in most cases we mean the most remarkable feature of Ukrainians. Since the ancient times in the most difficult times of our history it is humour that positively influenced the life, joined human souls, strengthened and encouraged in the struggles with enemies' (Chub, 1974, p.120). It should be mentioned that at first Lesia wrote to the local Ukrainian newspaper and took the surname of her aunt who at the time lived in Poltava, which Lesia visited twice before World War II. Later, she sent her works to the magazine New Days that was published in Canada. In fact, she did not want to be anyhow influenced as a writer by the surname of her famous father. 'My father reads the works after they were published,' she says. 'He complained about the fact that I never asked him for any piece of advice, but I was certain in my intentions'. In her interview with the newspaper Young Ukraine Lesia Bohuslavets emphasizes the differences between Ukrainian Diaspora of Australia and The USA and Canada. She says, that Ukrainian Diaspora in Australia emerged only after World War II and immigrants were to rebuild the remnants and create Ukrainian centres and schools. They were poor and worked hard. Their diplomas were not verified. Lesia's father, who was a teacher, had to work manually with a spade. However, she claims that so much was done to preserve national identity. Boliukh (1974) says, 'Ukrainian affair', primarily not known in Australia at the time, soon became popular. It was the presence of Ukrainians in Australia that influenced the situation in general and made them known. In her works L. Bohuslavets writes that 'the foreign land unites people. Australians were astonished at how easy and quickly these foreigners got their aims' (Boliukh, 1974, p. 191). She emphasizes the importance of the publicity in the preservation of national identity. From the private communication it became clear that in every city inhabited by Ukrainians there were public groups lead by the main group whose duty was to elect the leader and other members of authority. The activity of Saturday schools that were widely opened by activists was associated with choirs, dancing and theatrical groups, bandurists, plast, sports organization, etc. All these people were connected with the public groups, regularly met at Ukrainian House that was either rented or bought. Bohuslavets speaks about the fact that all national and religious holidays were celebrated.

Boliukh (1974) in his work mentions that Ukrainian associations, public meetings of artists and literary activists and private relations positively influenced and emphasized the importance of Ukrainian issues. Moreover, it was a good way 'to keep youth interested in the traditions of their forefathers' (Boliukh, 1974, p. 222). To prolong this process in the future 'real Ukrainian marriages' were said to be of a great importance. It is proved statistically as approximately 55 per cent of all Australian immigrants' marriages are formed of Ukrainian spouses (Gandzilevska, 2013). Lesia Bohuslavets demonstrates this theory by the example of her own life. She says she would never get married to the foreigner and she did not. Her husband Viktor Tkach comes from Dnipropetrovsk and it is he whom she owes much of what she has today. He supported her ambitions and backed her up. Moreover, in her impressions after the journey, the writer mentions that once she told her husband about her intention of visiting Ukraine it was followed by his remark that she 'would teach people even there how to live a dissent life' (Bohuslavets, 1984, p. 7). He continues saying that after her visit to Ukraine the whole nation will speak Ukrainian language.

To have enough time to spend with her two sons and two daughters she was much involved in the house chore and occasionally, six months before Christmas, worked at the factory. In her interview Lesia assumes that it was mostly because of the amount of time spent with her children that they did not forget Ukrainian language. However, she was a member of Ukrainian organizations (female organization, plast, sisterhood at church, etc.) that enabled her to experience 'the other side of life'. The writer emphasizes the importance of the church in the preservation of national identity of Ukrainians in Australia. From her personal letters it becomes clear that Ukrainian schools and universities that functioned at the time in Australia played a vital role in 
national preservation. She mentions University in Sydney, the Ukrainian department, of which was ruled by her sister Galyna Kosharska, the University named after Monash in Melbourne, controlled by Professor Marko Pavlyshyn. Such values as the relation to the ideals of independent Ukraine, the ability to keep Ukrainian self-consciousness among those who form Diaspora, active involvement in Ukrainian social structure are in the list of features that were considered as the most important for identity preservation. Moreover, two main problems that were considered in the researches were the formation of institutions, the main purpose of which is to preserve Ukrainian language, culture and patriotic forms of historical and political self-understanding, and the acquaintance of the world with the problems of Ukrainians (Gandzilevska, 2013).

In the context of national identity preservation, the almanac 'New Horizon'(1960), published by father of Lesia Bohuslaves Dmytro Nytchenko is a striking example of the collective works of Ukrainian writers and artists the works of who were aimed at the creation and successful running of artistic units and Ukrainian life in general. Thus, taking everything mentioned above into consideration it can be assumed that Ukrainian Australians donated millions of annual profits on the needs of Ukrainians being run by the intention to preserve Ukrainian heritage.

Tereshchenko (2009) and Boryshevsky (2006) define national identity as the feeling of resemblance to the nation, its history, past and present, responsibility for Motherland and certainty about concrete deeds realization. He mentions about two blocks, which constitute the structure of national identity. These are cognitive and affective blocks. Thus, the first is made of several components among which there are the knowledge of national group existence, the belonging to the national group, the knowledge about the territory, emblem, symbols, institutions, customs and traditions, historic dates, figures, the belief in the relation of the individual to the national group. The elements that make the second of the two above mentioned blocks include subjective importance of national identity, the level of apprehension of the national identity which is the ability to refuse it and the importance of membership in the group, the feeling of belonging to the national group, the feeling of apprehension that relates to the territory, social feelings such as shame, proud, national guilt and national self respect.

\section{Sample of Research}

In line with the aim of the research, a set of identifiers that make national identity were worked out. These were taken from the work of Udod (2010) who mentions about five integral factors of national identity. Each one is observed below with genuine precision. The first factor is human inclinations. As far as Udod is concerned, the nation exists as long as its members see each other as people who are joined by their origin, agree on the similarities they share and are certain about their intentions to prolong their staying together. The second element is common past that includes victories and losses, common obligations and common future. Next go common actions which are the solutions and achievements that make activity identification. The fourth element is common territory, motherland and country. This element creates the link between the nation and the state as a political institution that legally acts on certain territory. Finally, there are common characteristics that make a national character, common culture, common political principles such as democracy and lawfulness (Udod, 2010, p. 34).

Smith (1994) speaks about national identity as the feeling of political unity that unifies all the members of the community by means of obligations, duties and rights. He summarizes the integral parts of national identity, concluding that territory, laws, institutions and system of customs are to unify the cultural community (Smith, 1994, p. 16). The model that comprises all the elements mentioned above scientist calls western model. It presupposes the existence of the other model, opposite to the one described before. It is based on the principle of common origin and culture of the nation. In other words, Smith claims that territory of a particular nation does not influence the membership of its inhabitants, the belonging to which is specified immediately at one's birth. 
Content analysis appears to be a good way to examine the language of the literary work of Lesia Bohuslavets 'My Australian kuma'. The decision was justified by the fact that content analysis is "a research method for the subjective interpretation of the content of text data through the systematic classification process of coding and identifying themes or patterns" (Hsieh \& Shannon, 2005 , p. 1278). This quantification procedure allows researchers to specify the peculiarities of the way the national identity is revealed in Ukrainian immigrants who live in Australia and enables its integral elements indexation.

In the research, five elements mentioned by Udod (2002) were taken into consideration. Each factor was taken as a name for the block of the words of the semantic field which is understood as a set of words and phrases that illustrate the general idea of the block. Thus, the following blocks according to which the vocabulary units were grouped were selected: the collective identification a feeling of comradeship, friendship etc, common history and the feeling of belonging, active social life which is illustrated by one's participation in cultural activities, geographical belonging and national character, which is a set of cultural believes and traditions that are generally followed by Ukrainians.

As far as data for the research come from Bohuslavets's work 'My Australian kuma', the content was justified by the objectives. It was done with an aim to restore author's attitude towards the issue and her thoughts. The elements that were considered or conceptions of content were formed of lexical units such as words and phrases. According to the logic of content analysis, five above mentioned blocks were taken as research categories. In this particular research, every category (block) includes the units that are not used in any other categories (blocks). The procedure of the research presupposed the statistics of the general number of lexical units in the text, the number of words and phrases that make certain categories, which demonstrates its average validity, and the average coefficient of the variable that includes the information about the number of units in the category and their use in the text (Averianov, 2007). The conclusion about the validity was done on the basis of variables that were got as a result of content analysis.

\section{Results of Research}

To assess the linguistic material of 'My Australian kuma', every block was viewed in details. The whole procedure of content analysis was based on word counting. There were two variables viewed in the analysis: average validity or partial lexical distribution, which is the percent of lexical variety in the category, and average coefficient of the variable or average lexical coefficient $\mathrm{G}$. The first is taken from the comparison of the general number of words in the text and the number of lexical units within a certain category. It illustrates the ability of the author to use particular vocabulary and to express the idea by means of rich lexical system. The latter is a subjective criterion that presupposes vocabulary analysis of certain category as to its importance and efficacy. Thus, any of the above mentioned criteria can be considered in the analysis as an index of the importance of a particular category. However, the average lexical coefficient $G$ is seen in the paper as the most informative. It reflects the importance of the category not depending on how lexically numerous the category is.

Every set of vocabulary units that the categories were made of was verified so that the results of the research are reliable. Classification reliability is possible under the condition of category definition formulation. Thus, the first category 'collective identification' is understood in the research as one's feeling of belonging to the same society. It mainly explains the idea that only individuals driven by the collective feeling of belonging to one social group can prolong the existence of the group. In other words, it is a category that comprises the vocabulary units that illustrate comradeship, friendship or any other type of membership in a social group. It is a type of intergroup behaviour that is characterised by interpersonal relations. General number of words in the text 'My Australian kuma' is 20,813 words. In the category 'collective identification' the most frequently used lexical units were 'self-esteem', 'national duty', 'patriotism', 
'predecessor'. General number of words that were used by the author in the text is 120 that makes the average variable of $0.67 \%$. Concerning the index of frequency of word use in the category, the average coefficient of the variable is 5.2.

The category 'common history' is viewed as one's recollection of the past. It is a memory of generations that includes one's feeling of being either proud or ashamed of the facts that once occurred in the history of the nation. The vocabulary of the category comprised such units as 'past', 'Communists', 'decedents'. General number of words in the block is 95, which makes an average variable $0.46 \%$. Average coefficient of the variable is 4.9 .

Category 'social life' includes the lexical units like 'public meeting', 'plast', 'impressa', 'magazine'. By active social life one's involvement in importance social events and meetings is meant. As far as the majority of important decisions were made within the social groups, the peculiarities of this category could possibly reflect the level of importance of the group life. Thus, the general number of words in the category is 190 that makes the average variable $0.91 \%$. An average coefficient $\mathrm{G}$ is 6.7 .

Geography means one's belonging to the same territory. Immigrants are those people who were born on the territory of Ukraine and because of various reasons once left its territory. Thus, to the category 'geographical belonging' the following words were put: 'Carpathian', 'Ukraine', 'moskal'. General number of words in the category is 81 , the average variable is $0.39 \%$, average coefficient is 5 .

Finally, the category ' national character' included 139 words and got the average variable $0.58 \%$, average coefficient equals 6.1 . For this category mainly the words that mean one's relation to the state, religiousness and the knowledge of traditions are put. By this, amid the most frequently used words in this category are 'religion', 'language', 'respect' etc. National character of can be viewed as a system of relations of a particular ethnic group, in our case Ukrainians, to the surrounding world, which is reflected in their physical and religious peculiarities and is a main factor that distinguish them from other nationalities.

So far, the analysis of the vocabulary frequency and its importance demonstrates that immigrants of Australia preserve their national identity mainly by their active social participation in various meetings and celebrations. It can be seen as an exceptional case of Ukrainian immigrants to get together, being joined by the feeling of national belonging. It is further proved by the high coefficient of the category 'national character', which takes the second place after the category 'social life'. The importance of other categories cannot be neglected as their influence is arguably high. However, as far as the aim of the research was to define the categories that are the most influential for national identity preservation of Ukrainian immigrants in Australia, that appeared vital to find out categories that were marked as the most contextually obvious.

\section{Discussion}

The findings reported in this paper suggest a number of interesting hypotheses about the indicators of national identity of Ukrainian immigrants of Australia. Bellow they were ranged with a view of the variables that they were marked with. Thus 'active social life' occupies the highest position in the list, being followed by, 'national character', 'collective identification', 'common history' and 'geographical belonging' accordingly.

Active social life is understood as a dynamic process of collective identification which is achieved in cultural meetings, professional and religious associations, political groups' activity etc. It can be partially explained by the fact that Ukrainian immigrants relate to their families and relatives who continue living in Ukraine, developing in such way their strategic involvement in national and cultural development, positively changing the system of identification which is reflected in their right for historic and cultural heritage, transforming the status of their native land. Moreover, social groups can be viewed as a powerful means of national development. Efficient work of groups of immigrants is possible under the condition of their consolidation and unification, so that their activity is well-planned and well-organised. Thus, social belonging and social activity proves to be of a great importance for the Ukrainian immigrants of Australia and proves the words of Lesia Bohuslavets. 
National character is viewed as a component of national psychology which is represented by the system of attitudes of individuals to the surrounding, which can be seen in a combination of mental stereotypes and patterns of behaviour (Korol, 2012, p.26). Ukraine, similarly to other nations, should be perceived through its culture which is much dependent on the conditions of Ukrainian nation's formation and development. The link between culture and religion can be described as automatic which can be described by the significance of religion in both personal and national life (Franklin, 2004, p.103). The preservation of religious and moral principles that are typical of Ukrainians appears to be more acute than geographical and historic belonging to one nation. Ukrainians are said to be extremely religious and family-oriented. Thus, language, religion and culture prove to be deeply integrated into the concept of their national identity. It is realised in the system of values, national psychology and the ability to preserve them in their families and following generations. Moreover, this category presupposes political consciousness that is sometimes realised in the establishment of a common state (Suleiman, 2003).

Collective identification is an understanding of one's belonging to a particular nation. It is stated in the feeling of membership and one's relevance to certain social group. Collective identification of Ukrainian immigrants is much preserved in their intergroup relations. Somehow, it is proved by the social nature of any human being, so that Ukrainians tend to form communities of various relations, often joining social relations with religious peculiarities of Ukrainian nation. 'Kuma' as a vocabulary unit means a woman, God's mother of one's child, who, according to the religious principles, is supposed to take care of the kid, being of no less importance than a biological mother.

Common history and common territory are the factors that can not be neglected in the examination of one's national identification. They influence the formation of national identity and prove to be less important in its preservation. One's awareness of historic facts develops the feeling of national belonging. Moreover, the presence of sacred places on the territory of Ukraine can be seen as an important means of national preservation. However, they were marked with the lower variables that can prove the fact they are arguably vital for national identity development but less efficient in national identity preservation.

\section{Conclusions}

All findings suggest that national identity is a unity of multiple elements. It is a component of national psychology which is understood as a system of attitudes and beliefs that are influential for the life and activity of an individual that belongs to a certain ethnic group and is represented in the peculiarities of national culture, customs and tradition. Besides, the investigation has illustrated that national identity is less concerned about national history and geography. Such finding can debunk any existing misconception or hypothesis about the difficulties of national identity preservation in immigrants who occasionally visit their motherlands even though being born in Ukraine. This can be assumed from the results taken from the work of Lesia Bohuslavets who was born on the territory of Ukraine and thus experienced its cultural and historic heritage. However, such phenomenon can possibly be not typical of those immigrants who were born in other countries which can be an implication for future research.

The results reported here support the hypothesis that cultural integration which is active participation in meetings and committees is vital as it unites people and provides them with the possibility to discuss the national and ethnic matters.

These conclusions emphasise the importance of national identity preservation as a way to prolong the existence of Ukrainian nation, its culture, moral values and religious devotion. Moreover, it sheds some light on the indicators of national identity that are demonstrated by Ukrainian immigrant who live in Australia. Finally, it acquaints young generation to the works of people whose names are kept less known than it should be, such as Lesia Bohuslavets. 


\section{References}

Angelutsa, P. (2001). Avstraliia nadzvychaina [Extraordinary Australia]. Retrieved 10 February, 2014 from http://www.redcliffedoctor.com.au/Book/UKR/Output/TOC.html

Averianov, L. (2007). Kontent analis [Content analysis]. Moskwa: RGIU.

Berger, P., \& Luckmann, T. (1966). The social construction of reality: A treatise in the sociology of knowledge. Garden City, NY: Anchor Books.

Berry, J. (1992). Cross-cultural psychology: Research and applications. Cambridge: Cambridge University Press.

Bohuslavets, L. (1984). Na proshchu do ridnoi zemli: vrazhennia z podorozhi [Pilgrimage to native land: impressions of the journey]. Melburn: Baida.

Boliukh, M. (1974). Ukrainska hromada v Avstralii [Ukrainian society in Australia]. Almanah Novyi Obriy, 5, 213-224.

Boryshevskiy, M. (1994). Psyhologichni zakonomirnosti rozvytku hromadianskoi spraimovanosti osobystosti [Psychological peculiarities of individual's social orientation]. Kyiv: Milenium.

Chub, D. (1974). Ukrainskiy humor ta iogo tvortsi [Ukrainian humour and its creators]. Almanah Novyi Obriy, 5, 120-125.

Franklin, S., Widdis, E. (2004). National Identity in Russian Culture. An introduction. Cambridge: Cambridge University Press.

Gandzilevska, G. (2013). Zberezhennia natsionalnoi identychnosti tvorchoiu diasporoiu ukraintsiv Avstralii [The preservation of national identity of Ukrainian artistic Diaspora in Australia]. Naukovi zapysky: Psychology and Pedagogy, 25, 21-25.

Gnatenko, P. (1997). Ukrainskiy natsionalnyy harakter [Ukrainian national character]. Kyiv: DOK_K.

Gnatenko, P., \& Pavlenko, V. (1999). Identichnost: filosofskiy i psihologicheskiy analis [Identity: philosophical and psychological analysis]. Kyiv: Art-Press.

Holsti, Ole R. (1969). Content Analysis for the Social Sciences and Humanities. Reading, MA: AddisonWesley.

Hsieh, H. F., \& Shannon, S. E. (2005). Three approaches to qualitative content analysis. Qualitative Health Research, 15 (9), 1277-1288.

Kominiarska, I. (2012). Ulas Samchuk: alter ego I alter idem [Ulas Samchuk: alter ego and alter idem]. Zhytomyr: Ruta.

Korol, L. (2012). Psyhologiia formuvannia natsionalnogo harakteru [Psychology of national character formation]. Ostrog: NAU OA.

Maltseva, O. Poema I. Kotliarevskogo 'Eneida' iak representatsiia ukrainskoi natsionalnoi identychnosti [I. Kotlairevsky's poem 'Eneid' as a representation of Ukrainian national identity]. Shied, 5 (96), 98-102.

Matsko,V. (2010). Kontseptsiia liudyny $i$ svitu v ukrainskiy diasporniy prozi XX stolittia [The concept of human and world in Ukrainian Ddiaspora's novels of XX century]. Kyiv.

Mead, G., \& Morris. Ch. (2009). Mind, self, and society: From standpoint of a social behaviorist. University of Chicago.

Smith, A. (1991). National Identity. Reno: University of Nevada Press.

Suleiman, Y. (2003). The Arabic language and national identity. A study in Ideology. Edinburgh: Edinburgh University Press.

Tereshchenko, K. (2009). Formuvannia iedynoi natsionalnoi identychnosti iak umova rozvytku suchasnogo suspilstva [Formation of united national identity as a condition of the development of modern society]. Aktualni problem psyhologii, 23, 188-194.

Udod, O. (2010). Pro rol i znachennia shkilnoi istorii u protsesi tvorennia natsionalnoi identychnosti [About 
role and meaning of school history in the process of national identity development]. Istoriia Ukrainy, $37,3-6$.

Voropaeva, T. (2009). Samoidentifikatsiia ukraintsev i ruskih na iuge Rossii i Ukrainy: kompleksnyi analiz [Self-identification of Ukrainians and Russians in the Southern parts of Russia and Ukraine]. Belgorod: BelGU.

Advised by Ihor Pasichnyk, National University of Ostroh Academy, Ostroh, Ukraine 